Tạp chí Khoa học và Công nghệ biển T11 (2011). Số 4. Tr 21 - 33

\title{
VI KHUẨN KHỬ SUNPHAT U'A ÂMM SỬ DỤNG DẦU THÔ DESULFOVIBRIO DESULFURICANS ĐH3P PHÂN LẬP TÙ GIẾNG KHOAN DÂU KHÍ MỎ ĐẠI HÙNG, VŨNG TÀU
}

\author{
NGUYẼ̃N THỊ THU HUYỀN, TRƯƠNG ĐẠI DƯƠNG, LẠI THUÝ HIỀN \\ Viện Công nghệ sinh học
}

\begin{abstract}
Tóm tắt: Vi khuẩn khư sunphat va ấm được biết đến tù lâu với khả năng tạo $\mathrm{H}_{2} \mathrm{~S}$ gây ăn mòn kim loại. Gần đây các nhà khoa học trên Thế giới đã công bố là các vi khuẩn này còn có khả năng phân hủy dầu thô ở điều kiện kỵ khí. Trong nghiên cứu này, lần đầu tiên, chúng tôi công bố khả năng sủ dụng dầu thô ở điều kiện ky khí của vi khuẩn khử sunphat ua ấm ở Việt Nam. Chủng vi khuẩn khư sunphat ua ấm ĐH3P được phân lập tù̀ giếng khoan dầu khí mỏ Đại Hùng, Vũng Tàu có khả năng sử dụng dầu thô. Chủng ĐH3P là vi khuẩn Gram âm, hình que cong, có tiên mao. Kết quả phân tích trình tư gen $16 S$ rRNA cho thấy chủng này là loài Desulfovibrio desulfuricans (99.8\% độ tuoong đồng). Điều kiện tối uu cho sinh truởng của chủng ĐH3P trong môi truoòng Postgate B cải tiến là $1 \%(v / v)$ dầu thô, $2-3 \% \mathrm{NaCl}(\mathrm{g} / \mathrm{l}), \mathrm{pH}$ 8 và nuôi cấy ở $30^{\circ} \mathrm{C}$. Trong điều kiện môi truờng tối uu cho sinh truởng, chủng này đã sư dụng được $6.5 \%$ hàm luợng dầu tổng số và thành phần dầu bị chủng này phân huỷ là các nparafin có mach $C \geq 45$ sau 1 tháng thử nghiệm ở điều kiện ky khí. Đây là nhũ̃ng dũ liệu rất quan trọng để cảnh báo thêm về mối nguy hại của vi khuẩn khử sunphat ua ấm đến quá trình khai thác, sử dụng và bảo quản dầu mỏ ở nước ta.
\end{abstract}

Tù khoá: Desulfovibrio, ĐH3P, Đại Hùng, sủ dụng dầu thô, vi khuẩn khư sunphat va ấm.

\section{MỞ ĐÀU}

Vi khuẩn khử sunphat (KSF) là 1 nhóm các vi khuẩn kỵ khí nghiêm ngặt sống trong môi trường yếm khí như là bùn đáy ao, hồ, trầm tích biển, có khả năng khử sunphat thành sunphua (Muyzer, Stam, 2008). Trong phòng thí nghiệm, KSF có thể chỉ sản sinh ra 1 lượng nhỏ khí $\mathrm{H}_{2} \mathrm{~S}$ nhưng trong tự nhiên, chẳng hạn như trong trầm tích, KSF có thể giải phóng một lượng đáng kể khí $\mathrm{H}_{2} \mathrm{~S}$. Khí này kết hợp với các ion kim loại sẽ tạo ra các muối kết tủa.

Cho đến nay, rất nhiều loài KSF đã được tìm thấy ở các mỏ dầu. Tuy nhiên, sự sinh trưởng của chúng đã làm chua hóa quá trình hình thành dầu mỏ do chúng đã sản sinh ra khí $\mathrm{H}_{2} \mathrm{~S}$ làm tăng lượng khí này lên trong các giếng dầu. Đồng thời chúng còn tham gia vào quá trình ăn mòn sinh học các thiết bị kim loại (Cord-Ruwisch et al., 1987; Vance, 
Thrasher, 2005). Điều này đã làm ảnh hưởng nghiêm trọng đến các vấn đề về kinh tế, sức khỏe, an toàn và kỹ thuật đối với khai thác dầu khí.

Trong quá trình sinh trưởng, các vi khuẩn này thường sử dụng các nguồn cơ chất ưa thích như là lactate và acetate. Việc nghiên cứu quá trình phân hủy các hydrocacbon dầu mỏ bởi nhóm vi khuẩn này đã được tiến hành trong thời gian gần đây và đã đạt được những thành tựu nhất định. Cho đến nay, nhiều chủng KSF có khả năng phân hủy hydrocacbon đã được phân lập (Kniemeyer et al., 2003; Cravo-Laureau et al., 2004; 2007; Ommedal, Torsvik , 2007). Vì thế, đối với công nghiệp dầu khí, việc nghiên cứu khả năng phân hủy dầu thô của KSF đang là một vấn đề nghiên cứu cấp thiết.

Ở Việt Nam, công nghiệp dầu khí cũng đang phải đối mặt với việc chua hóa dầu và ăn mòn thiết bị kim loại gây ra bởi nhóm vi khuẩn này, trong đó có KSF ưa ấm. Đó là bởi vì trong quá trình khai thác dầu khí ngoài khơi, một lượng lớn nước biển đã loại bỏ oxy thường được bơm vào các giếng dầu nhằm duy trì áp suất trong giếng và tăng cường khai thác dầu thứ cấp. Vì thế, các vi khuẩn bản địa xung quanh khu vực có dầu cũng được theo vào trong giếng khoan. Các điều kiện kỵ khí kết hợp với hàm lượng sunphat cao trong nước biển đã thúc đẩy sự sinh trưởng mạnh mẽ của KSF trong các giếng khoan cũng như hệ thống khai thác, tồn chứa và vận chuyển dầu (Lại Thúy Hiền và $c s, 2000$ ). Như vậy, đi kèm với lợi ích thu được từ khai thác thứ cấp nhờ bơm ép nước, tác hại của KSF theo nước biển vào giếng khoan (KSF ưa ấm) gây ra cũng không nhỏ. Tính đến nay, mới chỉ có một số loài vi khuẩn khử sunphat ưa ấm đã được phân lập từ các mỏ dầu Bạch Hổ, Vũng Tàu (Lại Thúy Hiền, Lê Phi Nga, 1992; Lại Thúy Hiền, Đặng Phương Nga, 1998). Gần đây, Nguyễn Thị Thu Huyền và đồng tác giả (2010) đã phát hiện khả năng sử dụng dầu thô làm nguồn cơ chất là hiện tượng khá phổ biến của KSF ưa ấm lấy từ giếng khoan dầu khí Vũng Tàu. Vì vậy, trong bài báo này, lần đầu tiên, chúng tôi công bố chủng khử sunphat ưa ấm ĐH3P phân lập từ mỏ Đại Hùng, Vũng Tàu có khả năng sử dụng dầu thô. Những kết quả thu được là cơ sở dữ liệu hữu ích góp phần vào việc xây dựng các chiến lược phòng ngừa và kiểm soát quá trình sản sinh khí $\mathrm{H}_{2} \mathrm{~S}$ sinh học trong giếng khoan dầu khí.

\section{VẬT LIỆU VÀ PHƯƠNG PHÁP}

\section{Vật liệu}

Chủng nghiên cúu. Chủng ĐH3P được phân lập từ giếng số 3 (giếng khai thác dầu thứ cấp bằng cách bơm nước biển từ ngoài vào) mỏ Đại Hùng, Vũng Tàu.

Môi trường và điều kiện nuôi cấy. Môi trường dùng để hoạt hóa KSF là môi trường Postgate $\mathrm{B}$ cải tiến $1 \% \mathrm{NaCl}$ [Lại Thúy Hiền và $c s, 2003$ ]. Môi trường dùng để phân lập 
và nghiên cứu khả năng sử dụng dầu thô của KSF ĐH3P là môi trường dầu thô trong đó cơ chất lactate và axetat trong môi trường Postgate $\mathrm{B}$ cải tiến $1 \% \mathrm{NaCl}$ được thay bằng cơ chất dầu thô và chất thêm cao men bị loại bỏ khỏi thành phần môi trường. Môi trường để thu sinh khối cho việc tách DNA tổng số là môi trường Postgate $\mathrm{C}$ với thành phần như sau: $\mathrm{KH}_{2} \mathrm{PO}_{4} 0.5 \mathrm{~g} / \mathrm{l}, \mathrm{KCl} 0.5 \mathrm{~g} / \mathrm{l}, \mathrm{NH}_{4} \mathrm{Cl} 1 \mathrm{~g} / \mathrm{l}, \mathrm{NaCl} 15 \mathrm{~g} / \mathrm{l}, \mathrm{CaCl}_{2} 0.06$ g/l, $\mathrm{Na}_{2} \mathrm{SO}_{4}$ 1g/l, $\mathrm{MgSO}_{4} 0.06 \mathrm{~g} / \mathrm{l}$, natri lactat $6 \mathrm{~g} / \mathrm{l}$, natri xitrat $0.3 \mathrm{~g} / \mathrm{l}$, nước biển $(200 \mathrm{ml} / \mathrm{l})$. Các thành phần chất thêm, vitamin và vi lượng tương tự như môi trường Postgate $\mathrm{B}$ cải tiến ngoại trừ hàm lượng $\mathrm{FeSO}_{4}$ được bổ sung là $0.004 \mathrm{~g} / \mathrm{l}$. Đối với môi trường thạch thì $12 \mathrm{~g}$ agar được bổ sung vào 1 lit môi trường. Tất cả các thí nghiệm đều được tiến hành nuôi cấy trong điều kiện kỵ khí ở $30^{\circ} \mathrm{C}$ (ngoại trừ thí nghiệm nghiên cứu ảnh hưởng của nhiệt độ) với $1 \%$ giống ban đầu đang ở giai đoạn pha log được hoạt hóa trong môi trường Postgate $\mathrm{B}$ cải tiến $1 \% \mathrm{NaCl}$.

\section{Phương pháp}

Phân lập. Mẫu KSF lấy từ giếng số 3 mỏ Đại Hùng được hoạt hóa lại trong môi trường Postgate $\mathrm{B}$ cải tiến $1 \% \mathrm{NaCl}$. Sau đó, mẫu này được nuôi cấy trong môi trường chứa $1 \%$ dầu thô (lặp lại liên tiếp) cho đến khi KSF ĐH3P có khả năng sinh trưởng trong môi trường chứa dầu thô làm nguồn cơ chất duy nhất. Việc phân lập đơn chủng KSF ĐH3P sử dụng dầu thô được tiến hành bằng phương pháp pha loãng tới hạn trong môi trường thạch chứa $1 \%$ dầu thô.

Nhuộm Gram. Sau khi cấy hoạt hóa, chủng ĐH3P được nuôi cấy trên môi trường Postgate $\mathrm{B}$ cải tiến $1 \% \mathrm{NaCl}$. Sau 24 giờ nuôi cấy, tiến hành nhuộm Gram và quan sát trên kính hiển vi quang học.

Quan sát hình thái tế bào bằng kính hiển vi điện tử quét. Chủng ĐH3P được cấy hoạt hóa trên môi trường Postage $\mathrm{B}$ cải tiến $1 \% \mathrm{NaCl}$. Sau đó, các chủng này được nuôi cấy trên môi trường chứa $1 \%$ dầu thô. Khi các chủng này sinh trưởng tốt, lọc bỏ cặn $\mathrm{FeS}$ rồi ly tâm 8000 vòng/phút ở $4{ }^{\circ} \mathrm{C}$ trong 10 phút để thu tế bào, rửa lại bằng $\mathrm{PBS}(\mathrm{pH}$ 7.2). Qui trình chuẩn bị mẫu và soi trên kính hiển vi điện tử quét HITACHI S4800 theo Phạm Thị Hằng và Lại Thúy Hiền (2010).

Phân tích trình tụ gen $16 S$ rRNA. Chủng ĐH3P được cấy hoạt hóa trên môi trường Postage $\mathrm{B}$ cải tiến $1 \% \mathrm{NaCl}$. Sau đó, các chủng này được nuôi cấy trên môi trường Postgate $\mathrm{C}$ trong 4 ngày ở $30^{\circ} \mathrm{C}$. Sau đó, lọc bỏ cặn $\mathrm{FeS}$ rồi ly tâm 8000 vòng/phút ở $4^{\circ} \mathrm{C}$ trong 10 phút để thu tế bào. DNA tổng sổ của các chủng này được tách theo kit tách DNA vi khuẩn (Qiagen, Mĩ). Chất lượng DNA tổng số được kiểm tra trên gel agarose. Các bước tiếp theo được tiến hành theo Sakiyama et al. (2009). 
Đánh giá ảnh huởng của các yếu tố môi truờng đến sinh trưởng của chủng ĐH3P trong môi trưòng chứa dầu thô. Các thí nghiệm nghiên cứu ảnh hưởng của hàm lượng dầu thô, nhiệt độ, nồng độ muối $\mathrm{NaCl}$ và $\mathrm{pH}$ đến sinh trưởng của chủng $\mathrm{ĐH} 3 \mathrm{P}$ đã tuần tự được thực hiện. Chủng ĐH3P được cấy hoạt hóa trên môi trường Postage $\mathrm{B}$ cải tiến $1 \% \mathrm{NaCl}$. Sau đó, các chủng này được nuôi cấy trên các môi trường có hàm lượng dầu thô, nhiệt độ, nồng độ muối $\mathrm{NaCl}$ và $\mathrm{pH}$ khác nhau. Sự sinh trưởng của các chủng KSF này trong các điều kiện khác nhau được đánh giá thông qua hàm lượng $\mathrm{H}_{2} \mathrm{~S}$ tạo thành (xác định bằng phương pháp chuẩn độ iot).

Phân tích hàm luọng dầu tổng số và thành phần dầu thô. Chủng ĐH3P được cấy hoạt hóa trên môi trường Postage $\mathrm{B}$ cải tiến $1 \% \mathrm{NaCl}$. Sau đó, chủng này được nuôi cấy trên môi trường chứa dầu thô. Sau 4 tuần nuôi cấy, hàm lượng dầu tổng số và thành phần dầu thô bị sử dụng bởi $\mathrm{DH} 3 \mathrm{P}$ sẽ được xác định bằng phương pháp tách dầu trong nước và phương pháp sắc kí khí.

\section{Xác định hàm lựng dầu tổng số bằng phương pháp tách dầu trong nước}

Lọc mẫu nuôi cấy ĐH3P trong môi trường chứa $1 \%$ dầu thô bằng giấy lọc. Dầu và các sản phẩm lơ lửng không tan trong nước được giữ trên giấy lọc. Giấy lọc sau đó được được rửa vài lần bằng cách nhúng trong cốc đựng chloroform và được thu hồi vào một cốc cân. Sau khi thực hiện xong bước này, phần lớn mẫu dầu sau thí nghiệm còn bám trên thành chai đựng mẫu. Vì vậy, tiến hành tráng rửa chai vài lần bằng chroroform và thu hồi vào cùng cốc cân nói trên. Để dung môi trong cốc cân bay hơi qua đêm ở điều kiện nhiệt độ $20^{\circ} \mathrm{C}$. Sau khi bay hơi hết dung môi. Cân cốc cân để xác định khối lượng dầu.

\section{Xác định thành phần dầu bằng phương pháp sắc kí khí}

Phân tích định lượng thành phần nhóm (speudo) và thành phần các n-parafin của mẫu dầu đến $\mathrm{C} 45+$ bằng cách thiết lập hệ số đáp ứng cho mẫu chuẩn định lượng n-paraffin với việc sử dụng chất lỏng chuẩn $244 \mathrm{TM} 1 \mathrm{P}$ với độ tinh khiết $\geq 99,5 \%$ như chất nội chuẩn và sử dụng hỗn hợp chuẩn định lượng Agilent $\mathrm{P} / \mathrm{N}$ gồm các n-parafin từ nC5-nC45 như một mẫu chuẩn định lượng đa cấu tử n-paraffin. Chế độ phân tích sắc ký khí mẫu dầu thí nghiệm và mẫu chuẩn định lượng như sau: Column (HP-5, 30 m x0.25 mm x0.25 $\mu \mathrm{m}$ ), Oven $\left(35^{\circ} \mathrm{C}(3 \mathrm{~min}), 4^{\circ} \mathrm{C} / \mathrm{min}\right.$ to $310(40 \mathrm{~min})$ ), Carrier (Helium, $44.4 \mathrm{ml} / \mathrm{min}$, pressure : 10.5 psig), Injection (Split $45: 1,330^{\circ} \mathrm{C}$ ), Detector (FID, $330^{\circ} \mathrm{C}$ ).

\section{KẾT QUẢ VÀ THẢO LUẬN}

\section{1. Đặc điểm hình thái khuẩn lạc và tế bào chủng ĐH3P}

Theo công bố của Nguyễn Thị Thu Huyền và đồng tác giả (2010), tập đoàn KSF 
ĐH3P có khả năng sử dụng dầu thô làm nguồn cơ chất duy nhất cho sinh trưởng. Để có thể hiểu rõ hơn về các đặc điểm sinh học của đơn chủng KSF có khả năng sử dụng dầu thô, chúng tôi tiến hành phân lập đơn chủng ĐH3P, và từ đó tiến hành nghiên cứu các đặc điểm sinh học của nó.

Khi nuôi cấy trên môi trường thạch chứa $1 \%$ dầu thô làm nguồn cơ chất, khuẩn lạc chủng ĐH3P có hình tròn, đen, mép khuẩn lạc không gọn, đường kính khuẩn lạc khoảng 2 mm (hình 1). Kết quả nhuộm Gram cho thấy chủng ĐH3P là vi khuẩn Gram âm. Kết quả này phù hợp với các nghiên cứu trong và ngoài nước rằng hầu hết KSF ưa ấm là các vi khuẩn Gram âm (Lại Thúy Hiền, Lê Phi Nga, 1992 ; Lại Thúy Hiền, Đặng Phương Nga, 1998; Muyzer, Stams, 2008). Quan sát hình thái tế bào trên kính hiển vi điện tử quét SEM cho thấy tế bào chủng $\mathrm{ĐH} 3 \mathrm{P}$ có hình que cong, có tiên mao có thể giúp cho chủng này di chuyển tốt hơn trong môi trường (hình 1). Đây cũng là một trong những hình dạng phổ biến của KSF (Madigan et al., 2009).

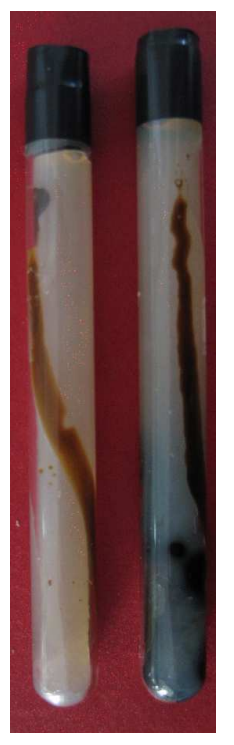

(A) ĐC ĐH3P

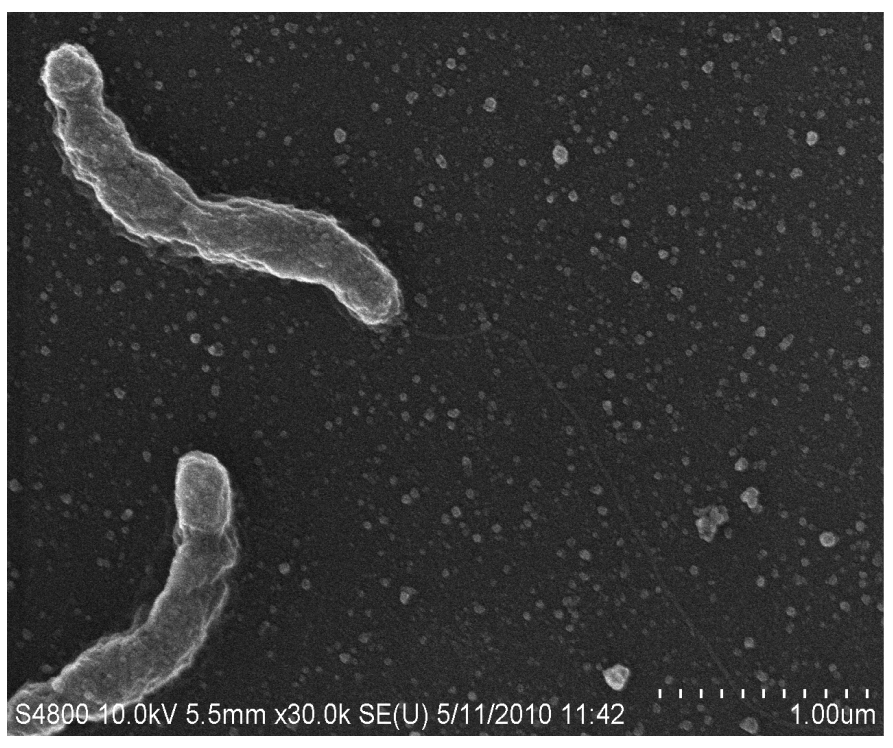

(B)

Hình 1: Hình thái khuẩn lạc $(\mathrm{A})$ và tế bào dưới kính hiển vi điện tử quét $(\mathrm{B})$ của chủng $\mathrm{DH} 3 \mathrm{P}$

\section{Xác định tên loài theo phân tích trình tự gen $16 \mathrm{~S}$ rRNA}

Để có thể tiến hành những nghiên cứu sâu hơn về khả năng sử dụng dầu thô của chủng ĐH3P, chủng này được định tên dựa trên phân tích trình tự $16 \mathrm{~S}$ rRNA. Kết quả phân tích được trình bày ở hình 2 . Kết quả cho thấy chủng này có độ tương đồng $99.8 \%$ 
với loài Desulfovibrio desulfuricans. Điều này hoàn toàn phù hợp bởi chi Desulfovibrio rất phổ biển trong nước biển Việt Nam.

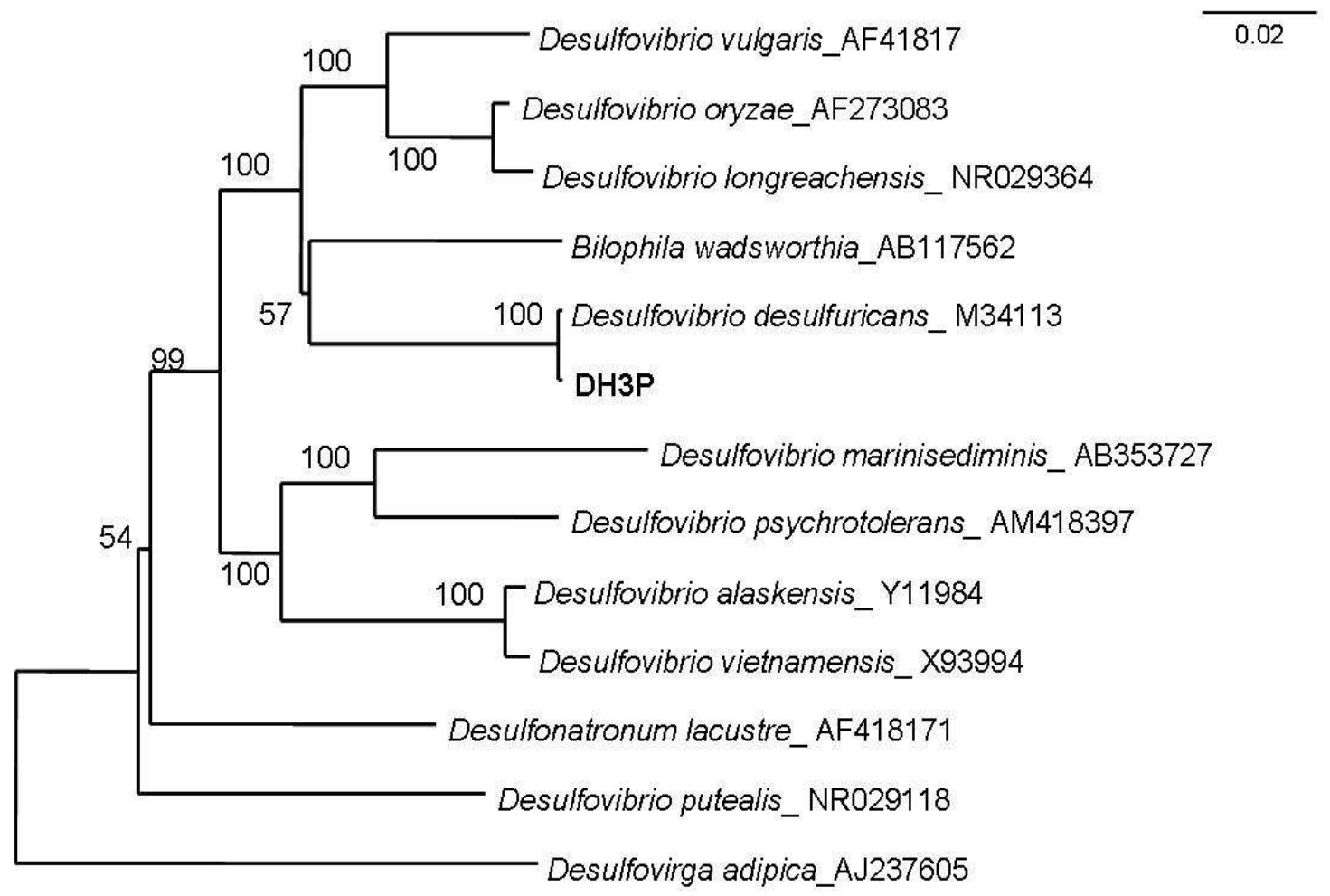

Hình 2: Vị trí phân loại của chủng KSF ĐH3P với các loài có quan hệ họ hàng dựa vào trình tự gen $16 \mathrm{~S}$ rRNA

\section{3. Ảnh hưởng của các yếu tố môi trường đến sinh trưởng của ĐH3P trong môi trường chứa dầu thô}

Để xác định được đâu là điều kiện tối ưu cho khả năng sinh trưởng của chủng ĐH3P khi nó sử dụng dầu thô làm nguồn cơ chất, ảnh hưởng của các yếu tố môi trường như hàm lượng dầu thô, nhiệt độ, nồng độ $\mathrm{NaCl}$ và $\mathrm{pH}$ đã được khảo sát. Kết quả được thể hiện ở hình 3.

Có thể thấy rằng chủng ĐH3P có khả năng sử dụng dầu khá cao. Nó có khả năng sinh trưởng trên nguồn cơ chất dầu thô từ $0.5 \%$ đến $20 \%$ (hình $3 \mathrm{~A}$ ). Chúng tôi cũng thử khả năng sử dụng dầu thô của vi khuẩn này trong môi trường chứa $30 \%$ dầu thô nhưng không thấy sự sinh trưởng của chủng này. Trong môi trường chứa $1 \%$ dầu thô thì chủng ĐH3P sinh trưởng tốt nhất (hình $3 \mathrm{~A}$ ). Các nghiên cứu khác nhau trên Thế giới đã cho thấy hàm lượng dầu ưa thích của KSF là từ $0.5 \%$ đến $5 \%$ (Rabus et al., 1996; Kniemeyer 
et al., 2003; Ommedal, Torsvik, 2007; Nakagawa et al., 2008). Do đó, kết quả nghiên cứu này là minh chứng khẳng định một lần nữa khoảng hàm lượng dầu thô ưa thích cho sinh trưởng của KSF.

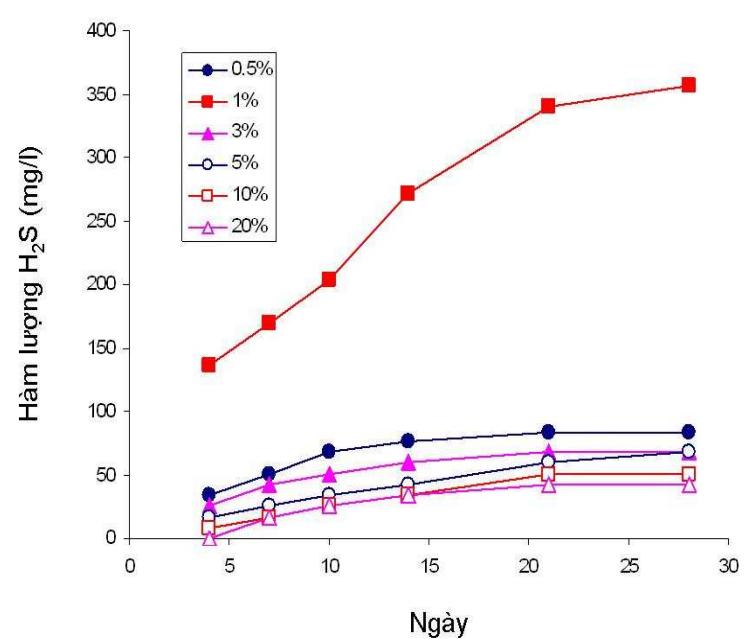

A

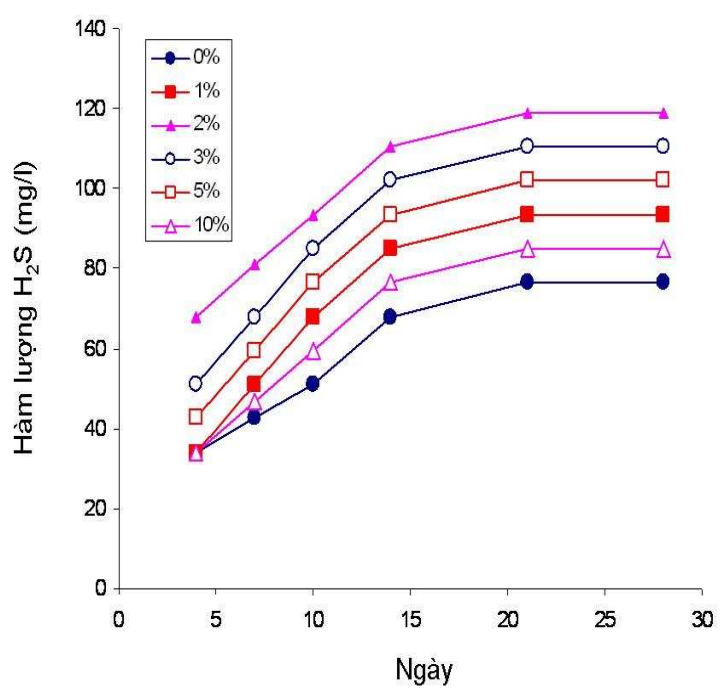

$\mathbf{C}$

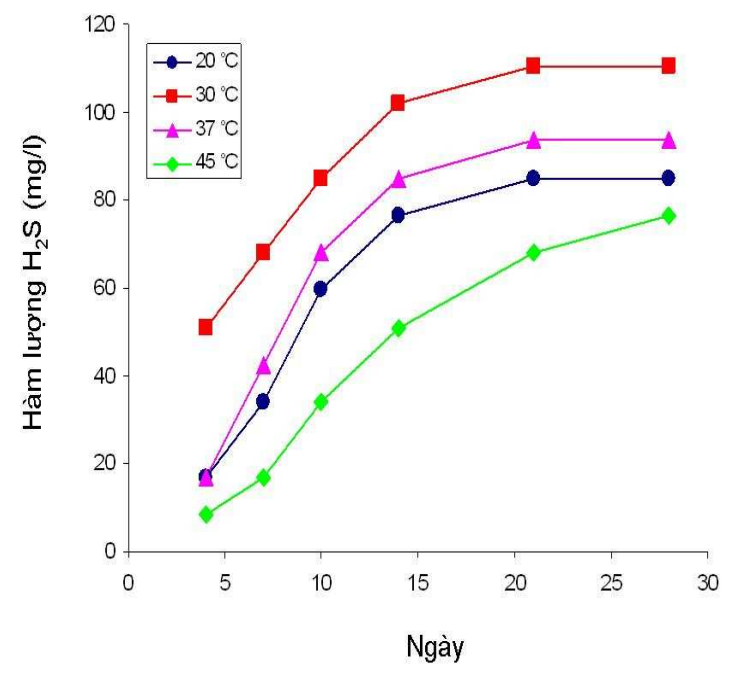

B

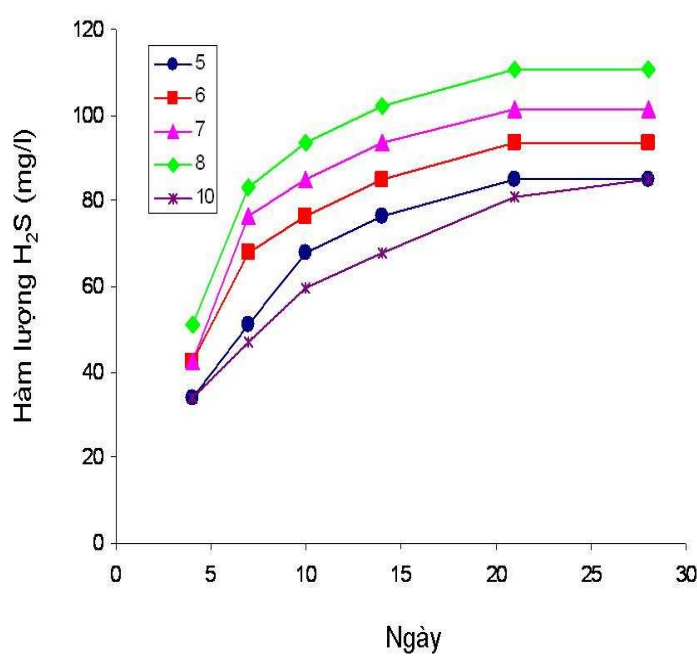

D

Hình 3: Hàm lượng $\mathrm{H}_{2} \mathrm{~S}$ tạo thành của chủng $\mathrm{ÐH} 3 \mathrm{P}$ trong môi trường có hàm lượng dầu thô (\% v/v) (A), nhiệt độ (B), nồng độ $\mathrm{NaCl}(\mathrm{C})$ và $\mathrm{pH}(\mathrm{D})$ khác nhau 
Như vậy khả năng sinh trưởng trong môi trường chứa dầu thô của ĐH3P là khá tốt (chỉ với hàm lượng nhỏ dầu thô, các chủng này vẫn có khả năng sinh trưởng được). Các chủng này sinh trưởng mạnh trên cơ chất dầu thô với hàm lượng $\mathrm{H}_{2} \mathrm{~S}$ sinh ra khá lớn $(\geq 40 \mathrm{mg} / \mathrm{l})$ sẽ là dấu hiệu cảnh báo sự tích tụ cao khí $\mathrm{H}_{2} \mathrm{~S}$ trong các giếng dầu của Vũng Tàu, nâng cao mối nguy hại cho sức khỏe công nhân và sự ăn mòn kim loại trong các đường ống dẫn. Điều đó đặt ra một thách thức lớn cho ngành công nghiệp dầu khí, làm thế nào để hạn chế được sự sinh trưởng của chúng trong các giếng dầu. Các yếu tố ảnh hưởng đến sinh trưởng của chủng này như nguồn cơ chất (dầu thô), nguồn chất nhận điện tử $\mathrm{SO}_{4}$ (nước biển) và các yếu tố môi trường (nhiệt độ, nồng độ muối $\mathrm{NaCl}$, $\mathrm{pH}$ ). Nguồn cơ chất thì không thể loại bỏ vì đây là giếng khai thác dầu. Nguồn chất nhận điện tử $\mathrm{SO}_{4}{ }^{2-}$ cũng khó hạn chế vì cho đến nay phương pháp bơm ép bằng nước biển vẫn là phương pháp hiệu quả để khai thác thứ cấp. Vì vậy, chỉ có yếu tố thứ 3 , yếu tố môi trường là có thể tác động được. Do đó, ảnh hưởng của các yếu tố môi trường (nhiệt độ, nồng độ muối $\mathrm{NaCl}, \mathrm{pH}$ ) đến sinh trưởng của nó lần lượt được nghiên cứu. Việc hiểu biết về các yếu tố này ảnh hưởng ra sao đến sinh trưởng của chúng sẽ cho ta phương pháp tác động hiệu quả nhất, làm thay đổi điều kiện sống tối ưu của ĐH3P, từ đó có thể hạn chế sự sinh trưởng của chủng này trong các giếng khoan ở Vũng Tàu.

Kết quả nghiên cứu ảnh hưởng của nhiệt độ đến sinh trưởng của chủng ĐH3P (hình $3 \mathrm{~B}$ ) cho thấy chủng này không sinh trưởng được ở $4^{\circ} \mathrm{C}$ và $55^{\circ} \mathrm{C}$, có khả năng sinh trưởng trong dải nhiệt độ từ $20^{\circ} \mathrm{C}$ đến $45^{\circ} \mathrm{C}$ và sinh trưởng tối ưu ở nhiệt độ $30^{\circ} \mathrm{C}$. Kết quả này phù hợp với khoảng nhiệt độ sinh trưởng của KSF ưa ấm [Davidova et al., 2006; CravoLaureau et al., 2007; Ommedal, Torsvik, 2007; Madigan et al., 2009].

Chủng ĐH3P phân lập từ giếng khoan dầu khí Vũng Tàu trên biển. Vì vậy, nồng độ $\mathrm{NaCl}$ là một trong những yếu tố ảnh hưởng trực tiếp đến sinh trưởng của nó. Do đó, chúng tôi tiến hành thử nghiệm chủng này trong môi trường có hàm lượng dầu thô tối ưu tại nhiệt độ tối ưu với các nồng độ muối $\mathrm{NaCl}$ khác nhau. Kết quả phân tích (hình $3 \mathrm{C}$ ) cho thấy chủng $\mathrm{ĐH} 3 \mathrm{P}$ có khả năng sinh trưởng trong khoảng từ $0 \% \mathrm{NaCl}$ đến $10 \% \mathrm{NaCl}$ và sinh trưởng tối ưu trong môi trường chứa $2-3 \% \mathrm{NaCl}$ (đây cũng là nồng độ muối của nước biển khu vực giàn khoan Vũng Tàu). Chủng này tách từ giếng khoan khai thác thứ cấp bằng cách bơm ép nước biển. Vì vậy, kết quả này cho thấy chủng này có thể có nguồn gốc từ nước biển bên ngoài giếng khoan.

Môi trường $\mathrm{pH}$ trung tính là môi trường thích hợp nhất đối với đa số vi khuẩn. Đối với $\mathrm{KSF}$, khoảng $\mathrm{pH}$ thích hợp nằm trong khoảng từ 6-9. Tuy nhiên, đối với từng loại $\mathrm{KSF}$ lại có $\mathrm{pH}$ thích hợp riêng. KSF ưa ấm có $\mathrm{pH}$ thích hợp nằm khoảng 6.8 - 7.5 . Tuy vậy chúng vẫn có thể sống được nếu $\mathrm{pH}$ giảm xuống đến 5 hay tăng lên đến 10 (Dang et $a l$., 1996; Lien, Beeder, 1997; Feio et al., 2004). Vậy chủng ĐH3P có khoảng pH tối ưu cho 
sinh trưởng giống như các KSF ưa ấm khác không? Để trả lời câu hỏi đó, chúng tôi tiến hành nuôi cấy các chủng này ở điều kiện hàm lượng dầu, nhiệt độ và nồng độ $\mathrm{NaCl}$ tối ưu với các $\mathrm{pH}$ môi trường khác nhau. Kết quả (hình $3 \mathrm{D}$ ) cho thấy chủng ĐH3P có khả năng sinh trưởng trong dải $\mathrm{pH}$ từ 5 đến 8 và $\mathrm{pH}$ trung tính hơi kiềm $(\mathrm{pH}$ 7-8) là $\mathrm{pH}$ tối ưu cho sinh trưởng của chủng này. Kết quả này một lần nữa khẳng định lại dải $\mathrm{pH}$ phù hợp cho sinh trưởng của KSF ưa ấm nói chung (Lien, Beeder, 1997; Feio et al., 2004; CravoLaureau et al., 2004; 2007) cũng như KSF ưa ấm phân lập từ giếng khoan dầu khí Vũng Tàu (Dang và cs, 1996; Lại Thúy Hiền, Đặng Phương Nga, 1998).

Tóm lại, các kết quả này sẽ là cơ sở giúp chúng ta có thể tạo ra một môi trường không thích hợp cho KSF, từ đó hạn chế được sự sinh trưởng của vi khuẩn này trong giếng khoan. Đồng thời cũng biết được các điều kiện môi trường tối ưu cho sinh trưởng của chủng này, để từ đó đánh giá khả năng sử dụng dầu thô của chủng này trong điều kiện tối ưu.

\section{4. Đánh giá khả năng sử dụng dầu thô qua biến đổi hàm lượng dầu tổng số và thành phần dầu mỏ}

Chủng KSF ĐH3P có khả năng sử dụng dầu thô cao. Tuy nhiên, chúng có khả năng sử dụng bao nhiêu phần trăm dầu và thành phần dầu được sử dụng như thế nào thì vẫn đang là câu hỏi còn để ngỏ. Để trả lời cho câu hỏi đó, chủng này được nuôi cấy trong môi trường tối ưu cho khả năng sử dụng dầu thô của chúng. Sau 30 ngày thí nghiệm, hàm lượng và thành phần dầu bị biến đổi trong mẫu thí nghiệm được phân tích.

ĐỒTH!̣ PHÂNBỐN-PARAFFINS

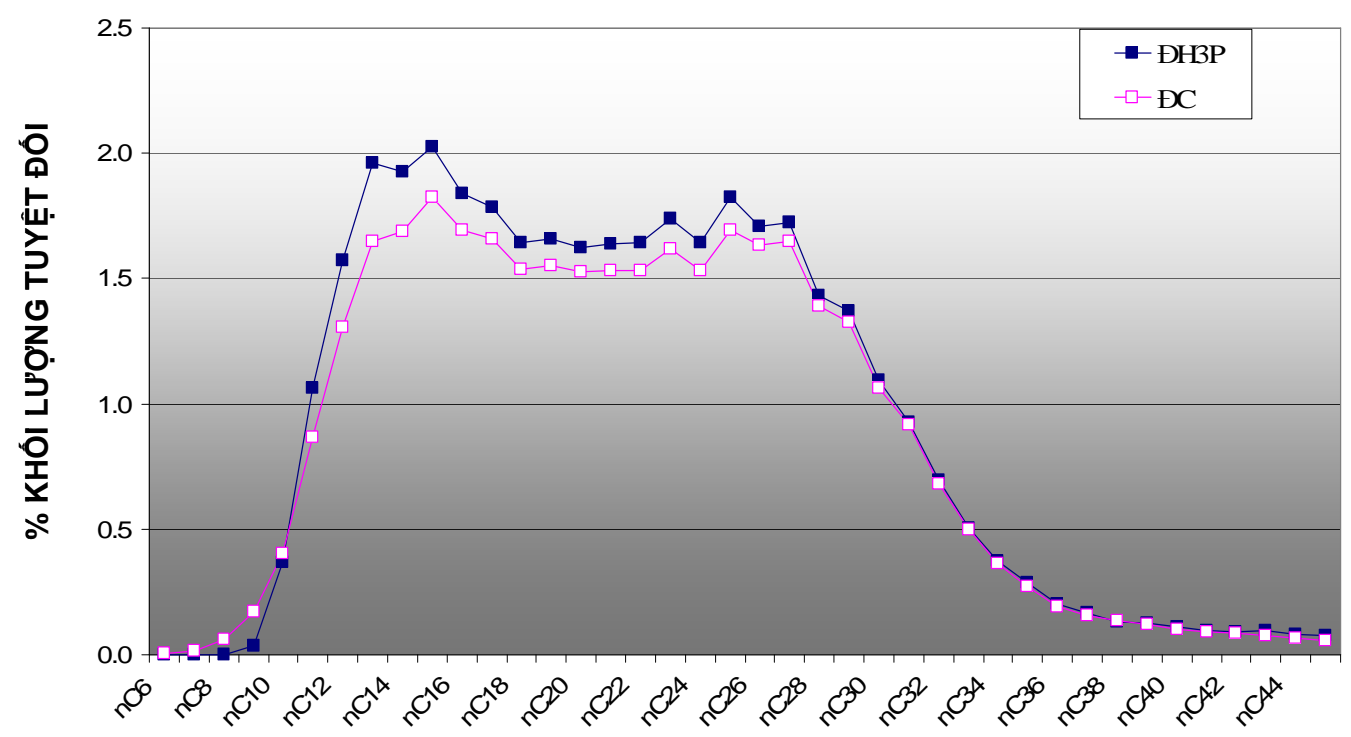

Hình 4: Thành phần n-parafin bị biến đổi sau 1 tháng thử nghiệm của chủng KSF ưa ấm ĐH3P so với đối chứng 
Kết quả phân tích hàm lượng dầu tổng số cho chủng ĐH3P sử dụng được $6.5 \%$ hàm lượng dầu tổng số. Kết quả phân tích thành phần dầu của mẫu đối chứng và mẫu thí nghiệm ĐH3P cho thấy các mẫu ĐH3P có hàm lượng n-parafin cao hơn so với mẫu đối chứng (hình 4). Điều đó chứng tỏ chủng này có khả năng sử dụng các thành phần dầu có hydrocarbon mạch dài $\mathrm{C} \geq 45$, ví dụ như asphaltene. Nhờ đó, dầu thô trở nên lỏng hơn. Do đó, có thể sử dụng những chủng này trong việc xử lý các phân đoạn hydrocacbon nặng $(\mathrm{C} \geq 45)$ sau khai thác.

\section{KẾT LUẬN}

Chủng vi khuẩn khử sunphat ưa ấm ĐH3P được phân lập từ giếng khoan dầu khí mỏ Đại Hùng, Vũng Tàu là vi khuẩn Gram âm, hình que cong, có tiên mao. Kết quả phân tích trình tự gen $16 \mathrm{~S}$ rRNA cho thấy chủng này thuộc loài Desulfovibrio desulfuricans $(99.8 \%$ độ tương đồng). Chủng ĐH3P sinh trưởng tối ưu trong môi trường chứa $1 \%(\mathrm{v} / \mathrm{v})$ dầu thô, $2-3 \% \mathrm{NaCl}(\mathrm{g} / \mathrm{l}), \mathrm{pH} 8$ và ở $30^{\circ} \mathrm{C}$. Chủng này đã sử dụng được $6.5 \%$ hàm lượng dầu thô tổng số và thành phần dầu bị chủng này phân huỷ là các n-parafin có độ dài $\mathrm{C} \geq 45 \mathrm{sau} 1$ tháng thử nghiệm ở điều kiện kỵ khí trong môi trường tối ưu cho vi khuẩn này sinh trưởng.

Lời cảm ơn: Công trình được thực hiện với sự hỗ trợ kinh phí trích từ đề tài cơ sở cấp Viện Công nghệ sinh học, Viện Khoa học và Công nghệ Việt Nam, mã số CSK0910_7 do TS. Nguyễn Thị Thu Huyền làm chủ nhiệm và với sự cộng tác của Viện Nghiên cứu Khoa học và Triển khai, Xí nghiệp khai thác dầu khí Vũng tàu Vietsopetro; Viện Vệ sinh dịch tễ Trung ương; Viện Vi sinh vật và Công nghệ Sinh học, Trường Đại học Quốc gia Hà Nội.

\section{TÀI LIỆU THAM KHẢO}

1. Cord-Ruwsich, R., Kleinitz, W., Widdel, F., 1987. Sulfate-reducing bacteria and their activites in oil production. Journal of Petroleum Technology, January: 97-106.

2. Cravo-Laureau, C., Labat, C., Joulian, C., Matheron, R., Hirschler-Réa, A., 2007. Desulfatiferula olefinivorans gen. nov., sp. nov., a long-chain n-alkenedegrading, sulfate-reducing bacterium. International Journal of Systematic and Evolutionary Microbiology 57(Pt 11): 2699-2702.

3. Cravo-Laureau, C., Matheron, R., Cayol, J.L., Joulian, C., Hirschler-Réa, A., 2004. Desulfatibacillum aliphaticivorans gen. nov., sp. nov., an n-alkane- and n- 
alkene-degrading, sulfate-reducing bacterium. International Journal of Systematic and Evolutionary Microbiology 54: 77-83.

4. Dang, P.N., Dang, T.C.H., Lai, T.H., Sta-Lotter, H., 1996. Desulfovibrio vietnamensis sp. nov., a halophilic sulfate-reducing bacterium from Vietnamese oil field. Anaerobe 2: 385-392.

5. Davidova, I.A., Duncan, K.E., Choi, O.K., Suflita, J.M., 2006. Desulfoglaeba alkanexedens gen. nov., sp. nov., an n-alkane-degrading, sulfate-reducing bacterium. International Journal of Systematic and Evolutionary Microbiology 56: 2737-2742.

6. Feio, M.J., Zinkevich, V., Beech, I.B., Llobet-Brossa, E., Eaton, P., Schmitt, J., Guezennec, J., 2004. Desulfovibrio alaskensis sp. nov., a sulphate-reducing bacterium from a soured oil reservoir. International Journal of Systematic and Evolutionary Microbiology 54: 1747-1752.

7. Kniemeyer, O., Fischer, T., Wilkes, H., Glöckner, O.F., Widdel, F., 2003. Anaerobic Degradation of Ethylbenzene by a New Type of Marine Sulfate-Reducing Bacterium. Applied and Environmental Microbiology 69 (2): 760-768.

8. Lại Thúy Hiền, Đặng Phương Nga, 1998. Một số đặc điểm sinh lý, sinh hóa của một số chủng vi khuẩn KSF phân lập từ mỏ dầu Bạch Hổ. Tạp chí Sinh học 20(2): 33-38.

9. Lại Thuý Hiền, Lê Phi Nga, 1992. Nghiên cứu khả năng gây ăn mòn kim loại của vi khuẩn Desulfovibrio vulgaris. Tạp chí sinh học 14(4): 26-29.

10. Lại Thuý Hiền, Đỗ Thu Phương, Lê Phi Nga, Đặng Phương Nga, Phạm Thu Thuỷ, Hoàng Hải, Phạm Thị Hằng, 2000. Khu hệ vi sinh vật trong khu vực dầu khí Vũng Tàu và hướng ứng dụng các vi sinh vật hữu ích. Hội nghị Sinh học Quốc gia: 77-83.

11. Lại Thúy Hiền, Đỗ Thu Phương, Vũ Phương Anh, Nguyễn Thị Thu Huyền, Kiều Hưu Ảnh, 2003. Đặc điểm sinh lý, sinh hóa của một số chủng vi khuẩn khử sunphat ưa nhiệt phân lập từ giếng khoan dầu khí Vũng Tàu. Tạp chí Khoa học công nghệ 41(4): 1-7.

12. Lien, T., Beeder, J., 1997. Desulfobacter vibrioformis sp. nov., a sulfate reducer from a water-oil separation system. International Journal of Systematic Bacteriology 47(4): 1124-1128.

13. Madigan, M.T., Martinko, J.M., Dunlap, P.V., Clark, D.P., 2009. Brock biology of microorganism. Pearson Education, Inc.: 141-174; 398-444. 
14. Muyzer, G., Stams, A.J.M., 2008. The ecology and biotechnology of sulphatereducing becteria. Nature Reviews Microbiology 6(6): 441-454.

15. Nakagawa, T., Sato, S., Fuku, M., 2008. Anaerobic degradation of p-xylene in sediment-free sulfate-reducing enrichment culture. Biodegradation 19: 909-913.

16. Nguyễn Thị Thu Huyền, Trương Đại Dương, Lại Thúy Hiền, 2010. Khảo sát khả năng sử dụng dầu thô của vi khuẩn khử sunphat phân lập từ giếng khoan dầu khí Vũng Tàu. Hội nghị Khoa học kỷ niệm 35 năm Viện Khoa học và Công nghệ Việt Nam 1975-2010, Tiểu ban Khoa học sự sống: 208-218.

17. Ommedal, H., Torsvik, T., 2007. Desulfotignum toluenicum sp. nov., a novel toluene-degrading, sulphate-reducing bacterium isolated from an oil-reservoir model column. International Journal of Systematic and Evolutionary Microbiology 57(Pt 12): 2865-2869.

18. Phạm Thị Hằng, Lại Thúy Hiền, 2010. Nghiên cứu vi khuẩn Dietzia sp. A343.4 mới phát hiện trong JetA1 và ảnh hưởng của nó đến chất lượng nhiên liệu máy bay. Tạp chí Công nghệ sinh học 8(3A): 853-863.

19. Rabus, R., Fukui, M., Wilkes, H., Widdel, F., 1996. Degradative Capacities and 16S rRNA-Targeted Whole-Cell Hybridization of Sulfate-Reducing Bacteria in an Anaerobic Enrichment Culture Utilizing Alkylbenzenes from Crude Oil. Applied and Environmental Microbiology 62(10): 3605-3613.

20. Sakiyama, Y., Nguyen, K.N.T., Nguyen, M.G., Miyadoh, S., Duong, V.H., Ando, K., 2009. Kineosporia babensis sp. nov., isolated from plant litter in Vietnam. International Journal of Systematic and Evolutionary Microbiology 59: 550-554.

21. Vance, I., Thrasher, D.R., 2005. Reservoir souring: mechanisms and preventation. In Ollivier B and Magot M, eds. Petroleum microbiology. ASM press, Washongton, DC: $123-142$.

CRUDE OIL-ULTILIZING STRAIN DESULFOVIBRIO DESULFURICANS DH3P, A MESOPHILIC SULFATE-REDUCING BACTERIUM ISOLATED FROM DAIHUNG OIL FIELD, VUNGTAU

\section{NGUYEN THI THU HUYEN, TRUONG DAI DUONG, LAI THUY HIEN}

Summary: Mesophilic sulfate-reducing bacteria were well known as a factor to cause microbial metal corrosion for long time ago. Recently, they have been discovered as 
organisms that can degrade crude oil in anaerobic condition. In the present work, it firstly reported that mesophilic sulfate-reducing bacteria isolated from Vietnam can also utilize crude oil in anoxic condition. A crude oil-utilizing, mesophilic sulfate-reducing bacterium, strain DH3P, was isolated from Daihung field, Vungtau. The cells were found to be Gramnegative, curved rod shape, and to have a flagellum. On the basis of 16S rRNA gene sequence analyses, strain DH3P is Desulfovibrio desulfuricans (99.8\% identity). Optimum growth of strain DH3P in crude oil medium occurred at $1 \%(\mathrm{v} / \mathrm{v})$ crude oil, $2-3 \% \mathrm{NaCl}(\mathrm{w} / \mathrm{v}), \mathrm{pH} 8$ and $30^{\circ} \mathrm{C}$. In optimal conditions, strain DH3P can consume $6.5 \%$ of crude oil total and oxidize heavy crude oil $(\geq C 45)$ for one month at anoxic condition. These results are first, important data for warning more harmful effects of sulfate-reducing bacteria on oil exploitation, utilization and preservation in Vietnam.

Key words: crude oil utilization, Daihung, Desulfovibrio, DH3P, mesophilic sulfatereducing bacteria

Ngày nhận bài: 07 - 7 - 2011

\section{Ngưòi nhận xét: PGS. TS. Lê Gia Hy}

